\title{
Language Lists
}

2.1 European Language Families (Scaliger 1610) 33

2.2 The Indo-European Family (c. 1820) 42

2.3 The Indo-European Family (Schleicher 1861) 46

2.4 The Indo-European Family (c. 1900) 54

2.5 The Indo-Hittite Family (Bloomfield 1933) 56

2.6 The Indo-European Family (Voegelin \& Voegelin 1977) 56

2.7 The Indo-Hittite Family (1986) 58

2.8 The Uralic Family (1986) 68

2.9 Proposed Subgroupings of the Finnic Family 69

2.10 The Uralic-Yukaghir Family (Collinder 1965) 70

2.11 Proposed Subgroupings of the North Caucasian Languages 74

2.12 The Caucasian Family (Gamkrelidze \& Gudava 1974) 74

3.1 African Language Families (Lepsius 1880) 79

3.2 African Language Families (Müller 1877) 79

3.3 African Language Families (Meinhof c. 1912) 81

3.4 African Language Families (Westermann 1940) 81

3.5 African Language Families (Greenberg 1949-50) 81

3.6 The Afro-Asiatic Family (Greenberg 1950) 83

3.7 The Niger-Congo Family (Greenberg 1954) 83

3.8 The Macro-Sudanic Family (Greenberg 1954) 83

3.9 African Language Phyla (Greenberg 1963) 84

3.10 The Hamito-Semitic Family (late 19th century) 88

3.11 The Hamito-Semitic Family (Lottner 1860) 89

3.12 The Afro-Asiatic Family (Greenberg 1950) 89

3.13 The Cushitic Family (Greenberg 1963) 90

3.14 Proposed Subgroupings of the Afro-Asiatic Family 91 
3.15 The Semitic Family (Hetzron 1972, 1974) 92

3.16 The Chadic Family (Newman 1977) 92

3.17 The Berber Family (Militarev 1984) 93

3.18 The Omotic Family (Fleming 1976a,b, 1981) 93

3.19 The Niger-Congo Family (Greenberg 1963a) 97

3.20 The West Sudanic Family (Westermann 1927) 98

3.21 The Kordofanian Family (Greenberg 1963a) 99

3.22 The Niger-Kordofanian Family (Bennett \& Sterk 1977) 100

3.23 The Mande Family (Welmers 1971) 101

3.24 The West Atlantic Family (D. Sapir 1971) 101

3.25 The Kru Family (Lafage 1978) 102

3.26 The Gur Family (Manessy 1978) 102

3.27 The Adamawa-Ubangian Family (Boyd 1978, Barreteau \& Moñino 1978, Bouquiaux \& Thomas 1980) 102

3.28 The South Central Niger-Congo Family (Bennett \& Sterk 1977, Greenberg 1974, and others) 103

3.29 The Nilotic Family (Köhler 1955) 110

3.30 The Nilo-Saharan Family (Greenberg 1963) 111

3.31 The Nilo-Saharan Family (Greenberg 1971, Bender 1982) 112

3.32 The Khoisan Family (Greenberg 1949-50/1954, 1963) 117

4.1 The Tatar Family (Strahlenberg 1730) 128

4.2 The Scythian Family (Rask 1834) 128

4.3 The Altaic Family (Schott 1849) 129

4.4 The Ural-Altaic Family (20th century) 129

4.5 Proposed Subgroupings of the Altaic Family 131

4.6 The Altaic Family (Street 1962, Patrie 1982) 132

4.7 The Turkic Family (Voegelin \& Voegelin 1977) 133

4.8 The Mongolian Family (Binnick 1981) 133

4.9 The Tungus Family (Voegelin \& Voegelin 1977) 133

4.10 The Chukchi-Kamchatkan Family 136

4.11 The Dravidian Family (Konow 1906) ${ }_{13} 8$

4.12 The Dravidian Family (Zvelebil 1974) 139

4.13 The Dravidian Family (Andronov 1978, McAlpin 1981) 140

4.14 The Elamo-Dravidian Family (McAlpin 1981 and others) 141

4.15 The Indo-Chinese Family (19th century) 143

4.16 The Indo-Chinese Family (Conrady 1896) 143

4.17 Proposed Subgroupings of the Sino-Tibetan Family 144

4.18 Proposed Subgroupings of the Tibeto-Burman Family 146

4.19 The Sino-Tibetan Family (Benedict 1942, Shafer 1955, and others) $\quad 146$

4.20 The Austric Family (Schmidt 1926) $\quad 151$

4.21 The Austric Family (Benedict 1942) 152 
4.22 The Austro-Tai Family (Benedict 1975) 153

4.23 The Austric Family (Greenberg 1980) 153

4.24 Proposed Subgroupings of the Austroasiatic Family 155

4.25 The Austroasiatic Family (Diffloth 1982) 156

5.1 The Austronesian Family (Schmidt 1926) 163

5.2 Proposed Subgroupings of the Austronesian Family 165

5.3 The Austronesian Family (Blust 1978, Pawley 1972, and others) $\quad 167$

5.4 The Indo-Pacific Phylum (Greenberg 1971) 176

5.5 The Trans-New Guinea Phylum (Wurm 1982) $\quad 178$

5.6 Papuan Language Phyla Other Than the Trans-New Guinea Phylum (Wurm 1982) $\quad 178$

5.7 The Indo-Pacific Phylum (Greenberg 1971, Wurm 1982) 182

5.8 The Australian Family (Walsh \& Wurm 1982, Black 1982) 189

6.1 The Eskimo-Aleut Family (Krauss 1976, 1979) 194

6.2 The Na-Dene Family (Sapir 1929 and others) 199

6.3 New World Language Families (Brinton 1891) 208

6.4 Language Families North of Mexico (Powell 1891) 209

6.5 North American Families (Sapir 1929) 214

6.6 Central American Families (Sapir 1929) 215

6.7 North American Families (Voegelin \& Voegelin 1967) 217

6.8 North American Families (Campbell \& Mithun 1979) 218

6.9 Central American Families (Campbell 1979) 219

6.10 New World Families (Greenberg 1960) 220

6.11 The Amerind Phylum (Greenberg 1987) 230

6.12 The Algonquian Family (Goddard 1978a,b, 1979) 231

6.13 The Salish Family (Thompson 1979) 232

6.14 The Caddoan Family (Chafe 1979) 232

6.15 The Siouan Family (Rood 1979) 233

6.16 The Iroquoian Family (Mithun 1979) 233

6.17 The Hokan Stock (Sapir 1929 and others) 234

6.18 The Penutian Stock (Sapir 1929, Greenberg 1987, and others) 235

6.19 The Tanoan Family (Davis 1979) 236

6.20 Proposed Subgroupings of the Uto-Aztecan Family 237

6.21 The Uto-Aztecan Family (Lamb 1964 and others) 237

6.22 The Oto-Manguean Family (Rensch 1976) 238

6.23 The Chibchan-Paezan Stock (Greenberg 1987) 238

6.24 The Andean Stock (Greenberg 1987) 239

6.25 The Macro-Tucanoan Stock (Greenberg 1987) 239

6.26 The Equatorial Stock (Greenberg 1987) 240

6.27 The Macro-Carib Stock (Greenberg 1987) 240

6.28 The Macro-Panoan Stock (Greenberg 1987) 241 
6.29 The Macro-Ge Stock (Greenberg 1987) 241

7.1 The World's Language Families (Ruhlen 1987) 258

7.2 Proposed Subgroupings of the Eurasiatic (= Nostratic)

Phylum 259

7.3 The World's Language Families (Greenberg 1987) 260

8.1 Representation of the Branching-Tree Diagram of Family X 281 